JOSAR, Vol. 1 No. 1 March 2019; p-ISSN: 2502-8251; e-ISSN: 2503-1155

Copyrights@ Balitar Islamic University, Blitar-Indonesia https://ejournal.unisbablitar.ac.id/index.php/josar

\title{
DEVELOPING ADOBE FLASH PROFESSIONAL AS A LEARNING MEDIA TO INCREASE THE FIRST GRADE STUDENTS' SPEAKING ACHIEVEMENT AT JUNIOR HIGH SCHOOL IN THE 2018/2019 ACADEMIC YEARS
}

\author{
Yunia Wulandari ${ }^{1}$, Dian Fadhilawati ${ }^{2}$ \\ Universitas Islam Balitar; JalanMajapahit No 2-4 Sananwetan Kota \\ BlitarJawaTimur- 66137 Indonesia \\ English Education, FKIP Universitas Islam Balitar, Blitar \\ Email: 'yunia17blt@gmail.com , ${ }^{1}$ dianfadhilawati@yahoo.com
}

\begin{abstract}
The research was Research and development which intended to develop a valid and effective model of Adobe Flash Professional as a Learning Media to Increase the First Grade Students' Speaking Achievement at Junior High School especially on the topics Greeting and leave taking as well as apologizing. This reseacrh applied Research and Development (R\&D) design, based on Sugiyono model.which include : Analyzing potential and problem, Data collection, Product design, Product validation, Product revision, Product testing/try-out, Product revision and Final product. The subject of this research were 29 students of VII C in MTs Ma'arif NU GandusariBlitar. The data of the research were quantitative data ( the result from Test and Questionnaire) and qualitative ( the result of interview)The result of the research showed that: (1) The developed product (adobe flash profesional) as a learning media was valid, it was proved by the result of content English material validation (77.4\%) and media validation (70.4\%); (2) Developed Adobe flash professional as a learning mediawas effective to increase the first grade students' speaking achievement, it was proved by the increasement of the students' speaking mean score of Greeting and Leave Taking from (43.40) to (80.50) and score of Apologizing from (45.00) to (91.70); (3) Students gave positive responses toward the developed adobe flash professional as a learning media in teaching speaking reflected from the result of questionnire given (80.80\%). From the result above, it can be concluded that adobe flash professional as a learning media was valid to be applied in teaching learning and effective to increase the first grade students' speaking achievement at MTs Ma'arif NU GandusariBlitar.
\end{abstract}

Key Words : Adobe Flash Professional, Learning Media, Speaking Achievement, Research and Development

\section{INTRODUCTION}

There are four skills in teaching and learning English: Listening, Speaking, Reading and Writing. Those skills are related to each other and cannot be separated each other, therefore learners need to master all of four language skills. Uma and Ponnambala (2001) state that mastering language skills will determine the students' communicative competence in 


\section{JOSAR, Vol. 1 No. 1 March 2019; p-ISSN: 2502-8251; e-ISSN: 2503-1155 \\ Copyrights@ Balitar Islamic University, Blitar-Indonesia https://ejournal.unisbablitar.ac.id/index.php/josar}

the target language. The goal of communicative competence is mainly to make the students speak up. Therefore learning speaking is the most important skills that should be learnt compare with others skill.

However, most of the students considered speaking as difficult skill to be mastered.Speaking is very difficult to be mastered, because most of the students don't have adequate vocabulary, grammar knowledge, and ability to pronounce the words in English correctly. Dito (2014) states that speaking, as one of major four skills has sub skills that are needed to be mastered in order to be a good speaker, such as grammar, vocabulary, and pronunciation. Therefore, in learning speaking the students need to master many aspects such as, grammar, vocabulary, and pronunciation.

Furthermore, the problemsin learning speaking faced by the students in MTS Ma'arif NU Blitar especially in class VII C. Based on the results of documentation from school most of the students' achievement in learning speaking were below the minimum criteria mastery of the school. The mean score of the students was (56.75) it was below the minimum criterion mastery of the school (80.00)Furthermore, based on the result of interview on $8^{\text {th }}$ May 2018 with the headmaster it was known that the school used 2013 curriculum as learning foundation however the school didn't have complete facilities to support teaching learning process, in addition, based on the result of interview with the English teacher it was known that the teacher rarely use intereresting media because the media for teaching learning especially speaking were lack.

To overcome the problem in that school especially in teaching and learning speaking, it is necessary interesting media, one of the interesting media that can be use to teach speaking is Adobe Flash Professional. Adobe Flash Professional is multimedia platform originally acquired by macromedia and is currently being developed and distributed by adobe systems. According to Sajdah (2016) the benefit of the use of Adobe flash professional as a learning media to teach speaking are (1) Can create objects in appropriate with the wishes of developers, ranging from images, sounds, or animated movement. (2) More interactive. (3) The resulting program can run or stand alone without having to have a program or install Adobe Flash first before operating it. (4) Create a smoother animation or image.

The effectiveness of the use of Adobe flash Professional as learning media in teaching learning had been proved by researchers such as Nurul Anggaini (2015) whoproved that Adobe Flash Professional was effective to be used to make learning media because the used of this media that developed by adobe flash professional got good responses from teachers and students, and could increase the students' learning 
JOSAR, Vol. 1 No. 1 March 2019; p-ISSN: 2502-8251; e-ISSN: 2503-1155

Copyrights@ Balitar Islamic University, Blitar-Indonesia https://ejournal.unisbablitar.ac.id/index.php/josar

motivation and achievement. In addition, Sadjah (2016) proved that adobe flash professional was effective to increase students' value. The students also more active in teaching learning process in the classroom because they operate the media by them selves.

Based on the problem faced by the school, the benefit of the use of Adobe Flash Professional as a learning media, the result of previous researches, the researchers were interested to develop an interactive media to increase the students' speaking achievement under the title "Developing Adobe Flash Professional as a Learning Media to Increase the First Grade Students' Speaking Achievement in Junior High School in the 2018/2019 Academic Years".

\section{RESEARCH METHODOLOGY}

The design of this research was Research and Development ( $R$ \& D). Sugiyono (2016: 297) says research and development is one of the research methods used to produce a product, the effectiveness of the product has been tested. This research used $R \& D$ methods that attempt to produce or develop a product which can be justified. To be able to produce a certain product done needs analysis and to test the effectiveness of product.

In this research there were seven procedures that used by the researchers; 1) data collection, finding potential, problem and solution; 2) design and development; 3) expert validation and revision; 4) trial/try out; 5) evaluation by expert; 6) revision and 7) final product. These seven procedures were elaborated into seven phases of this research which consist of (1) preliminary study (phase I); (2) design and development (phase II); (3) expert validation and revision (phase III); (4) experimental study (phase IV); (5) evaluation by expert and revision (phase V); (6) final product (phase $\mathrm{VI}$ ). The research procedure described in the following figure: 
JOSAR, Vol. 1 No. 1 March 2019; p-ISSN: 2502-8251; e-ISSN: 2503-1155

Copyrights@ Balitar Islamic University, Blitar-Indonesia https://ejournal.unisbablitar.ac.id/index.php/josar

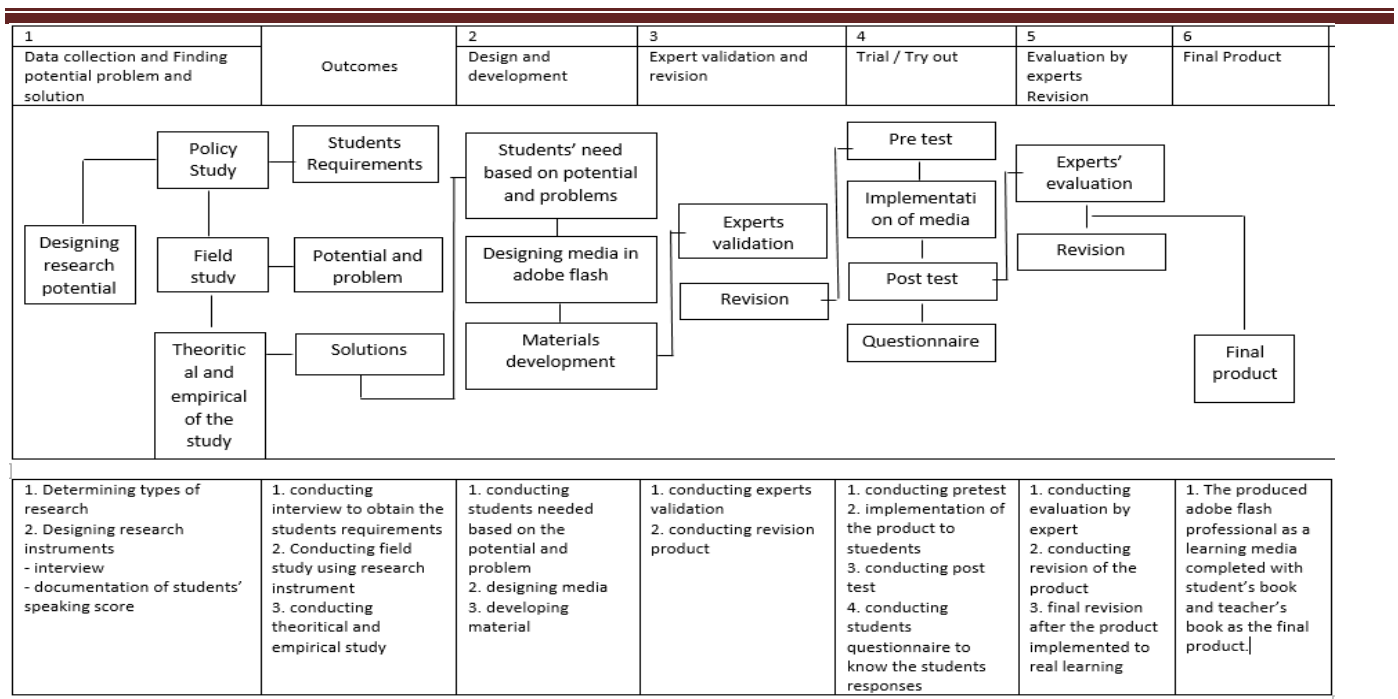

Figure 1 research framework of motion pictures to increase the first grade students' speaking achievement at Junior High School, adapted from sugiyono, (2016: 298).

(1) Preliminary Study (Phase I)

Research and Development (R\&D) started from analyzing potential, problem and solution. In this research the researchers done policy study and literature study and field study in MTS Ma'arif NU GandusariBlitar. In this case the researchers chose VII C class as subject of the research.

\section{(2) Design and Development (Phase II)}

The development model used in the development of this product wasthe ADDIE Model. ADDIE is the acronym of analyze Design Development Implement Evaluate. Branch (2009:2-3) stated the educational philosophy for this application of ADDIE is that intentional learning should be student centered, innovative, authentic, and inspirational. The design scheme of the ADDIE learning model forms a cycle consisting of 5 stages consisting of: analysis, design, development, implementation and evaluation.

\section{(3) Expert Validation and Revision (Phase III)}

Design validation is a process to assess whether the product design is rationally more effective and durable than previous product or not (Sugiyono, 2016:536). In this research, the design validation in form of an assessment based on rational thought by experts, and have not been empirically tested. Assessmentdone by the expert before the product tested to the students. In this research, the researcher assisted by three experts. First expert was Mrs. DF, the English lecturer of Islamic University of Balitar Blitar as a firstmaterial expert and Mrs. YP, the English lecturer of Islamic University of Balitar Blitar as the second material expert, and 
JOSAR, Vol. 1 No. 1 March 2019; p-ISSN: 2502-8251; e-ISSN: 2503-1155

Copyrights@ Balitar Islamic University, Blitar-Indonesia https://ejournal.unisbablitar.ac.id/index.php/josar

the third expert Mr. DF, the lecturer of Information and Tecnology of Islamic University of Balitar Blitar as a media expert.

(4) Experimental Study (Phase IV)

This research was Research and Development (R \& D). Sugiyono (2016:297) said research and development is one of the research methods used to produce a product, the effectiveness of the product must be tested. This study used research methods that attempt to produce or develop a product which the results can be justified. To be able to produce a certain product needs to testthe effectiveness of the product.. This research used experimental design. According to (Sugiyono, 2016:72) experimental design used to find out the influence of certain treatments on others under controlled conditions. Experimental design devided into three, they were 1) one shot case study; 2) one group pretest posttest design and 3) intact group comparison. Among these experimental design the researcher used one group pretest posttest design.

(5) Evaluation By Expert and Revision (Phase V)

After the product tested to determine the extent impact of media after use in real learning. In this phase the researcher got evaluation and revision from the expert to know the effectiveness level and to identify the weaknesses and errors of each component in the media.

(6) Final Product (Phase VI)

After the product have been evaluated by expert, the researcher done revision based on the experts' evaluation. This phase is the last phase that aimed to obtain the complet product. At thie end of this phase is developing adobe flash professional as a learning media to increase the first grade students' speaking achievement at junior high school in the 2018/2019 academic years.

\section{RESEARCH FINDINGS AND DISCUSSION}

\section{Research Findings}

1. The Final Model of Adobe Flash Professional as a learning media to Increase the First Grade Students Speaking Achievement at Junior High School

The researcher created the final product. The final model of developing Adobe Flash Professional as a learning media to increase the first grade students' speaking achievement at junior high school. The final product was completed with guideline books (Teacher's book and Student's book).

Final Model of Adobe Flash Professional as a learning mediato Increase the First Grade Students' Speaking Achievement at Junior High School 
JOSAR, Vol. 1 No. 1 March 2019; p-ISSN: 2502-8251; e-ISSN: 2503-1155

Copyrights@ Balitar Islamic University, Blitar-Indonesia https://ejournal.unisbablitar.ac.id/index.php/josar

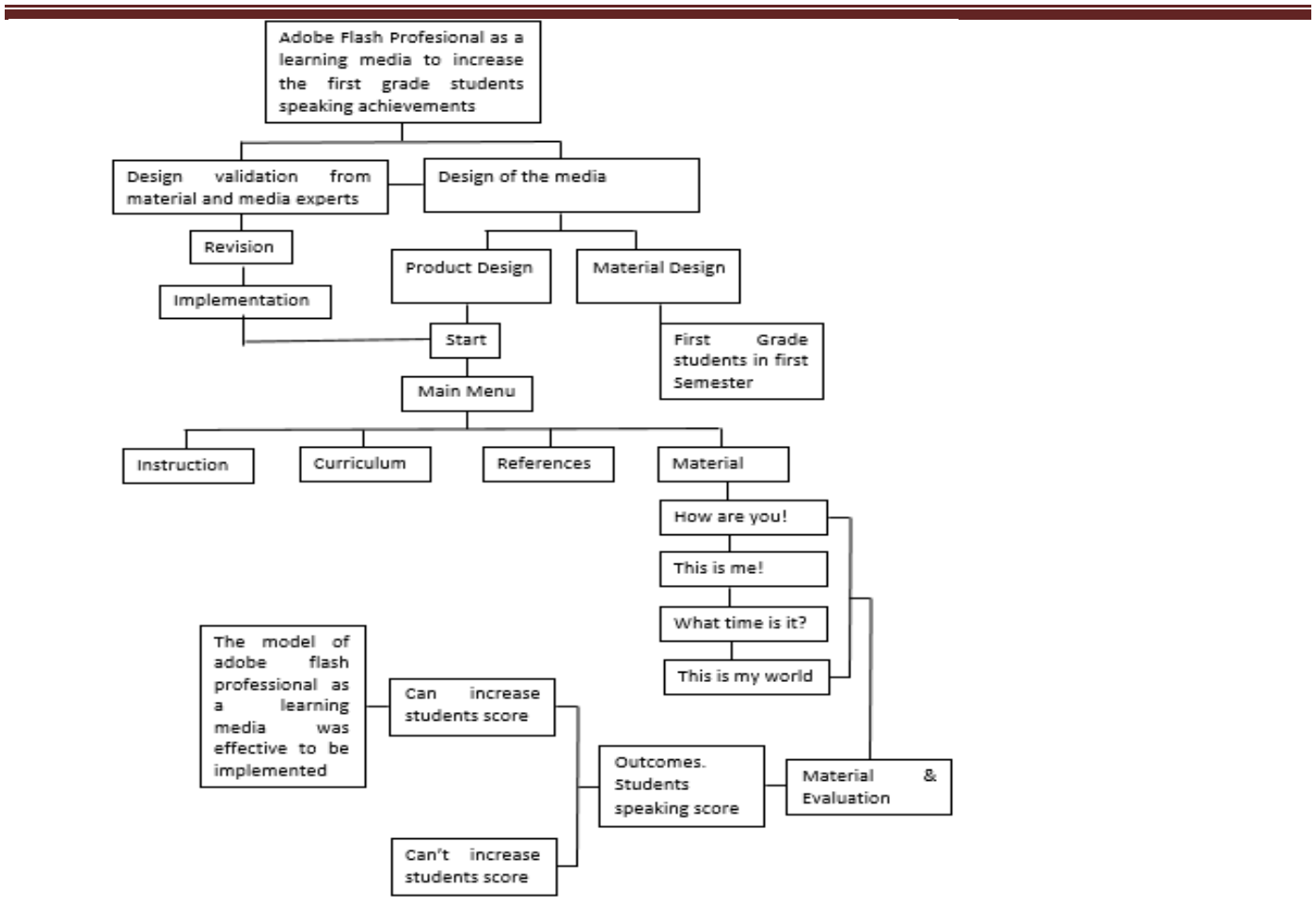

Figure 2 : Final Model of Adobe Flash Professional as a learning media to Increase the First Grade Students' Speaking Achievement at Junior High School

\section{Expert Validation}

The research of developing Adobe Flash Profssional as a Learning Media based on 2013 curriculum, to know the quality of the product, students response, the result of students' pre-test and post-test and to increase the first grade students' speaking achievement that has been developed in learning of MTs Ma'arif NU Gandusari. In this research, the product can be said valid if expert judgement gets sore $\geq 70 \%$ with category "Good", and students response gets score $\geq 70 \%$ with a category "Agree".

In this research, the researcher assisted by three experts. First, experts material, there were two experts material. The researcher used two experts because the researcher want the media that the researcher developed become more valid. The result of material validation from the first expert was $83.2 \%$ and the result of material validation from the second expert was $71.2 \%$. From the result above the researcher obtained a percentage was $77.4 \%$ and included the category "Good".

Table 1 : The Result Recapitulation of English speaking material

\begin{tabular}{ccccc}
\hline No & Validator & Component & $\begin{array}{c}\text { Percentage } \\
\%\end{array}$ & Criteria \\
\hline 1 & Expert of Material & Content of & $77.2 \%$ & Good \\
\hline
\end{tabular}


JOSAR, Vol. 1 No. 1 March 2019; p-ISSN: 2502-8251; e-ISSN: 2503-1155

Copyrights@ Balitar Islamic University, Blitar-Indonesia https://ejournal.unisbablitar.ac.id/index.php/josar

\begin{tabular}{ccccc}
\hline \hline \multicolumn{5}{c}{$\begin{array}{c}\text { English } \\
\text { material }\end{array}$} \\
\hline 2 & Expert of Media & Media & $71.2 \%$ & Good \\
\hline Average & & $74.2 \%$ & Good \\
\hline
\end{tabular}

\section{The Result of Students' Pre-test and Post-test}

To know the students' score before and after treathment, the researcher conducted pre-test and post-test. The researcher limit the material for pre-test and post-test just in Greeting and Leave taking; and Apologizing topics. The researcher held two times pre-test and post test. First pre-test and post-test for greeting and leave taking topics. Second pre-test and post-test for apologizing topics. The test was conducted to measure the students' speaking ability.

Pre-test greeting and leave taking was done on $19^{\text {th }}$ July 2018 . The result of the students' pre-test got low score, after the researchers calculating the score, they got mean score 43.10 this mean score was less than the criteria minimum score for English lesson in MTs Ma'arif NU Gandusari that was 80. 00 After the researcher knew the students' score based on pre-test, the researcher donetreatment by using media. Treatment using media was done to find out whether the use of media in teaching speaking was effective or not. After treating using the media the researchers continued the research phase by giving a post-test. Post-test

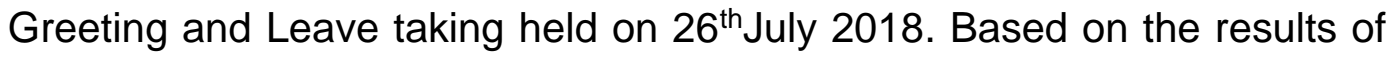
the post-test the researcher found out that, after the treatment using the media the students' scores in greeting and leave taking topics had increased from 43.1 to 80.5 .

Pre-test apologizing was done on July $27^{\text {th }} 2018$. The result of the students' pre-test got low score, after the researchers calculated the score, they got mean score 45.00, this mean score were less that criteria minimum score for English lesson in MTs Ma'arif NU Gandusari that is 80.00. After the researchers knew the students' score based on pre-test, the researchers done treatment using media. Treatment using media was done to find out whether the use of media in teaching speaking is effective or not. After treating using the media the researcher continued the research phase by giving a post-test. Post-test Apologizing held on August

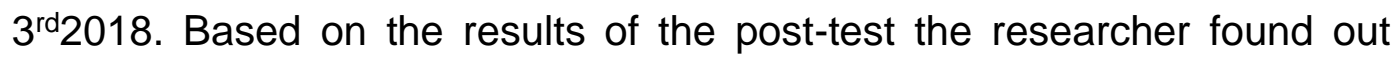
that, after the treatment using the media the students' scores in apologizing materials had increased from 45.00 to 91.7.

Based on the result of the students pre-test and post-test above, Adobe Flash Professional as a learning media was effective to increase 
JOSAR, Vol. 1 No. 1 March 2019; p-ISSN: 2502-8251; e-ISSN: 2503-1155

Copyrights@ Balitar Islamic University, Blitar-Indonesia https://ejournal.unisbablitar.ac.id/index.php/josar

speaking achievement of the first grade students at MTs Ma'arif NU Gandusari as presented in the following table:

Table 2 The Result of Try Out Greeting and Leave Taking

\begin{tabular}{|ll|ll|}
\hline Pre-test & & Post-test & \\
\hline Mean Score & 43.4 & Mean Score & 80.5 \\
Highest & 55 & Highest & 90 \\
Lowest & 35 & Lowest & 75 \\
t-value & -27.49 & Significances & $0.05 / 2.048$ \\
\hline
\end{tabular}

Table 3 The Result of Try Out Apologizing

\begin{tabular}{|c|c|c|c|}
\hline \multicolumn{2}{|l|}{ Pre-test } & \multicolumn{2}{|l|}{ Post-test } \\
\hline Mean Score & 45.0 & Mean Score & 91.7 \\
\hline Highest & 55 & Highest & 95 \\
\hline Lowest & 40 & Lowest & 85 \\
\hline t-value & -42.88 & Significances & $0.05 / 2.048$ \\
\hline
\end{tabular}

4.The Result of T-test

The calculation of t-test greeting and leave taking

\begin{tabular}{|l|r|r|}
\hline $\begin{array}{c}\mathrm{t} \text {-Test: Paired } \\
\text { Two Sample for } \\
\text { Means }\end{array}$ & $\begin{array}{c}\text { pre test greeting and } \\
\text { leave taking }\end{array}$ & $\begin{array}{c}\text { post test greeting and } \\
\text { leave taking }\end{array}$ \\
\hline Mean & 43,44827586 & 80,51724138 \\
\hline Variance & 32,32758621 & 23,83004926 \\
\hline Observations & 29 & 29 \\
\hline $\begin{aligned} \text { Df } \quad=\mathrm{n}-1 \\
=29-1 \\
=28 \text { (significances level on df } 28=>2.048 \text { with significances } 0.05)\end{aligned}$
\end{tabular}

T-table obtained from the significances level table is 2.048

T-count obtained from the t-test calculation is -27.49

So researcher conclude the valley of the significance as diagram below:

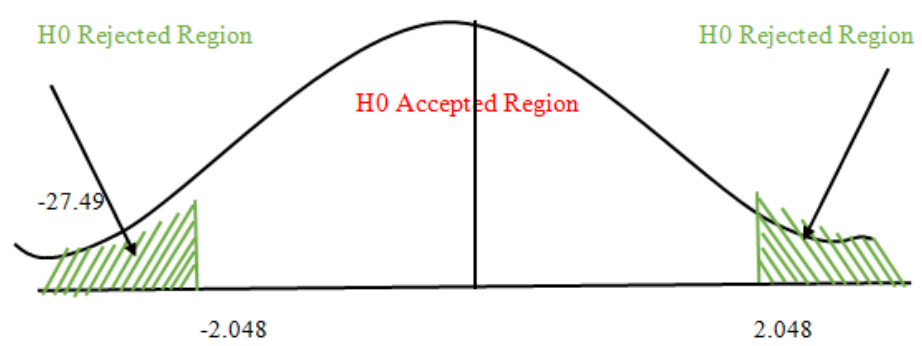

The conclusion from the valley diagram above is that, $\mathrm{Ho}$ is rejected, so it can be concluded, if there are significant differences between student learning outcomes in the greeting and leave taking topic before and after using Adobe Flash Professional learning media.

The calculation of t-test Apologizing 
JOSAR, Vol. 1 No. 1 March 2019; p-ISSN: 2502-8251; e-ISSN: 2503-1155

Copyrights@ Balitar Islamic University, Blitar-Indonesia https://ejournal.unisbablitar.ac.id/index.php/josar

\begin{tabular}{|l|r|r|}
\hline \hline $\begin{array}{l}\text { t-Test: Paired Two } \\
\text { Sample for Means }\end{array}$ & pre test apologizing & post test apologizing \\
\hline Mean & 45 & 91,72413793 \\
\hline Variance & 21,42857143 & 12,99261084 \\
\hline Observations & 29 & 29 \\
\hline
\end{tabular}

Df $\quad=\mathrm{n}-1$

$=29-1$

$=28$ (significances level on $\mathrm{df} 28=>2.048$ with significances 0,05 )

T-table obtained from the significances level table is 2.048

$\mathrm{T}$-count obtained from the t-test calculation is -42.88

So researcher conclude the valley of the significance as diagram below:

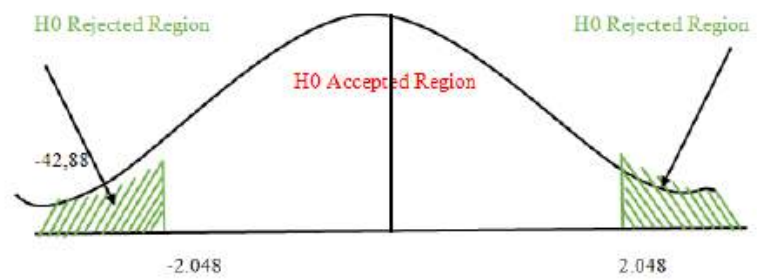

The conclusion from the valley diagram above is that, $\mathrm{Ho}$ is rejected, so it can be concluded, if there are significant differences between student learning outcomes in the apologizing topic before and after using Adobe Flash Professional learning media.

\section{5) The Result of Students' Responses}

To know the students' responses toward the media, the researcher used Questionnaire. The total score is 1187 of criterion score 1450 and the percentage result of the responses of the students $81.86 \%$ the value is included $80 \%<x \leq 100 \%$ and the criteia score is Absolutely Agree, it means the students' respons toward the used of media was very positive.

\section{Table 4 : The result of students' response}

\begin{tabular}{|c|c|c|}
\hline No & Item & Score \\
\hline 1 & 1 & 136 \\
\hline 2 & 2 & 134 \\
\hline 3 & 3 & 130 \\
\hline 4 & 4 & 139 \\
\hline 5 & 5 & 133 \\
\hline 6 & 6 & 55 \\
\hline 7 & 7 & 54 \\
\hline 8 & 8 & 130 \\
\hline 9 & 9 & 136 \\
\hline 10 & 10 & 140 \\
\hline \multicolumn{2}{|c|}{ Total Score } & 1187 \\
\hline \multicolumn{2}{|c|}{ Criterium Score } & 1450 \\
\hline \multicolumn{2}{|c|}{ Percentage } & $81.86 \%$ \\
\hline
\end{tabular}

\section{DISCUSSION}

The development of Adobe FlashProfessional was used to teach the first gradestudents' speaking achievement. The manufacturing process 
JOSAR, Vol. 1 No. 1 March 2019; p-ISSN: 2502-8251; e-ISSN: 2503-1155

Copyrights@ Balitar Islamic University, Blitar-Indonesia https://ejournal.unisbablitar.ac.id/index.php/josar

was carried out in stages and to produce the learning media that suitable for use in learning speaking skill, a series of validation processes were carried out with media experts, material experts and tested/try out. All series are intended to obtain data which is carried out revisions or improvements in order to achieve proper and useful learning media for user.

The results of the validation of material experts showed that Adobe Flash Professional as a learning media was good to use. With a percentage of $77.4 \%$ and included in the "Good" category this learning media is suitable to be used as a media for learning speaking skill. This is also supported by the results of the validation of media expert that received a percentage of $70.4 \%$ and included in the "Good" category.

After being declared feasible by material experts and media experts, this learning media was tested/try out to the first grade students. There were two test, first is pre-test Greeting and Leave Taking topic and Apologizing topic. Second is post-test Greeting and Leave Taking; and Apologizing topic. From the pre-test, students got score 43.1 for greeting and leave taking topic, and score 45 for apologizing topic. Whereas from the post-test, students got score 80.5 for greeting and leave taking topic, and score 91.7 for apologizing topic. Based on increasing students' scores before and after treatment, it can be seen that there were significant differences in students' grades. This shows that the learning media are in accordance with the needs of students.

The students' responses toward the use of the developed Adobe Flash Professional as a Learning Media to increase the first grade students' speaking achievement was $81.86 \%$. Those result was categorized "Good". It means that the students gave positive responses toward the use of developed Motion Pictures in their learning, especially in learning speaking.

\section{CONCLUSION}

The developed effective model of adobe flash professional as a learning media was effective to be implemented, it proved by the result of validation of the product which include, the result of content of English material validation was $77.4 \%$ while the result of media validation was $70.4 \%$ the score was categorized as "Good" with interval $60 \%<x \leq 80 \%$. The model of the product (adobe flash professional) as a learning media is in form of application that installed in the personal computer, notebook or laptop. The product designed as attractive as possible to attract students interest in learning speaking. The product contain the first grade students at junior high school (How are you? Good morning!; This is me!; What time is it?; and This is my world). Every chapter contain material in form of 
JOSAR, Vol. 1 No. 1 March 2019; p-ISSN: 2502-8251; e-ISSN: 2503-1155

Copyrights@ Balitar Islamic University, Blitar-Indonesia https://ejournal.unisbablitar.ac.id/index.php/josar

video animation, song related to the topic, and task to measure students ability in speaking after teach using the media. The final product is alternative media to learn speaking in class with the teacher and students' alternative learning media at home.

The developed adobe flash professional as a learning media was effective to increase the first grade students' speaking achievement at MTs Ma'arif NU Gandusari in the 2018/2019 academic years. It proved by the result of the achievement of the students' score in the topic Greeting and leave taking, they got 43.4 for the pre-test and 80.5 for the post-test as well as Apologizing topic, they got 45.0 for the pre-test and 91.7 for the post test. Furthermore, based on the calculating of t-test, t-value from of Greeting and leave taking was -27.49and t-vaue of Apologizing was 42.88 and the significance of t-table was 2.048. So, adobe flash professional as a learning media was effective to increase the first grade students' speaking achievement in teaching learning process especially in speaking skill.

Moreover, the students' responses toward the use of the developed adobe flash professional as a learning media was $81.86 \%$. Those result was categorized "Absolutely Agree". It means that the students gave positive responses toward the use of developed adobe flash professional in their learning, especially in learning speaking.

\section{Suggestions}

Based on the whole process of implementing the developmet research of the use of adobe flash professional as a learning media to increase the first grade students' speaking achievement at MTs Ma'arif NU Gandusari in the 2018/2019 academic year. Some suggestions are proposed to the following element:

1) For the students

The students needs more practice to increase their speaking.

2) For the teacher

The teacher may use the product (adobe flash professional) as an alternative strategies in teaching and learning speaking not only for the topics Greeting and apologizing but also for other topics for example : What time is it?

3) For future researchers

For the future researchers, the result of the reserach might be used as a references to conduct the research with another topic or research design. Furthermore it is also suggested for the future researchers to conduct a further research on the use of adobe flash professional in teaching other skills such as listening, reading, or writing. 
JOSAR, Vol. 1 No. 1 March 2019; p-ISSN: 2502-8251; e-ISSN: 2503-1155

Copyrights@ Balitar Islamic University, Blitar-Indonesia https://ejournal.unisbablitar.ac.id/index.php/josar

ACKNOWLEDGEMENT

The reseachers would like to give the greatest thanks and appreciation to the headmaster of MTs Ma'arif NU Gandusari Blitar, the English teacher and all staffs who supported the researchers in finishing the research.

\section{REFERENCES}

Andi, 2012. Kreasi animasi kartun dengan adobe flash. Yogyakarta : Andi Offset.

Anggaeni, N. 2015. Pengembangan Media Pembelajaran Berbasis Multimedia Interaktif Menggunakan Adobe Flash Cs5 Untuk Smk Kelas Xi Kompetensi Keahlian Administrasi. Yogyakarta : Yogyakarta state university.

Arsyad, azhar. 2014.media pembelajaran. Jakarta : Raja grafindo persada. Branch, M.R.2009. Instructional Design: The ADDIE Aproach.Springer New York Dordrecht Heidelberg London.London.

Brown, H.D. 2001. Teaching by principles: an interactive approach to language pedagogy. New york : addison weslye longman.inc.

Cohen, L. At all. 2007. Research Method and Education. New York : Taylor \& Francis e-Library.

Dermawan, D. 2014. Inovasi pendidikan. Bandung : remaja rosdakarya.

Hamdani, 2011. Strategi Belajar Mengajar. Bandung : CV Pustaka Setia Harjanto, 2006. Perencanaan pembelajaran. Jakarta : rineka cipta jakarta. Kusuma, P.B. 2013. Developing an english speaking material. Yogyakarta : Yogyakarta state university.

Permedikbud, No 22 tahun 2016. Tantang standar proses pendidikan dasar dan menengah. Jakarta : departement of National Education of Republic of Indonesia.

Sadiman, S. Arif. 2014. Media pendidikan, pengertian pengembangan dan pemanfaatannya. Jakarta : Raja grafindo.

Sajdah, P. 2016. Pengembangan Media Pembelajaran Pada KeterampilanMenyimak Berbasis Adobe Flash Cs6 Action Script 3Bersistem Operasi Android Pada Materi La Famille DanLes Activités Quotidiénnesuntuk Siswa Kelas XiSma N 1 Kota Mungkid. Yogyakarta : Yogyakarta state university.

Sugiyono, 2016. Metode Penelitian Kuantitatif, Kualitatif, dan R\&D.

Bandung : Alfabeta. 